\title{
CORRELATION BETWEEN CERTAIN PARAMETERS OF PIG CARCASS QUALITY IN UNCONVENTIONAL HOUSING SYSTEMS **
}

\author{
O. Kosovac ${ }^{* *}$, B. Živković ${ }^{1}$, T. Smiljaković ${ }^{1}, \check{C C}^{-R_{a d o v i c}}{ }^{1}$ \\ ${ }^{1}$ Institute for Animal Husbandry, Belgrade-Zemun, Serbia \\ *Correpsonding author: Olga Kosovac, e-mail: okos@sezampro.rs \\ **Originalni naučni rad (Original scientific paper) \\ Research financed by the Ministry of Science and Technological Development, Republic of \\ Serbia, Project TP 20087/08
}

Abstract: Major qualitative parameters of Landrace pig carcasses are presented in this paper. Phenotypic correlation between cracass quality indices and meat yield of carcass sides was investigated. Fatteners included in this research (117) were reared in non-conventional conditions, on deep litter, and as litter straw was used.

Meat yield of pig carcass sides was evaluated on the slaughter line using the «two point» method (Džinić et al. 2004) and mathematical model using FOM-device (defined by Petrović et al. 1996). Meat yield of carcass sides estimated using FOM was 56,29\%, and by method of »two points « 53,16\%. Of basic quality parameters of pig carcasses the strongest correlation assesed using FOM device was established between meat yield of carcass side and thickenss of fat tissue - LF and RF, and using the method of two points, between meat yield of carcass side and thickness of fat tissue - $\mathrm{X}_{1} \mathrm{i} \mathrm{X}_{2}$. Established correlations were negative, strong and statistically significant $\left(-0,85^{* *} ;-0,87^{* *}\right.$ and $\left.-0,97^{* *} ;-0,77^{* *}\right)$. Results of the assessment of quality of pig carcasses obtained using method of two points $(53,16 \%)$ and by instrumental method on right carcass sides using FOM device $(56,29 \%)$ differed, which indicates need to develop new equations for evaluation/assessment of share of muscle tissue in pig carcasses.

Key words: carcass quality, correlations, Landrace 


\section{Introduction}

In scientific paper, it is not sufficient only to establish values of certain parameters, but also to determine the relation between certain traits. Presence of certain relations and dependence between certain traits is causality.

Considering the increase of economical significance of fattening of meat pigs, in researches by some authors dependence between parameters of the quality of pig carcasses and meat yield of carcass sides was established (Senčić et al. 2002; Pulkrábek et al.,2004). It is known that it is not possible to determined the quantity of meat and fat tissue in carcass and its major parts based on exterior. However, by applying regression equations, it is possible to determine the quantity of meat and fat tissue in carcass sides, without detailed dissection, which is done in practice since cost of production and subsequent work are reduced. According to research results obtained in Croatia, shares of muscle and fat tissue in carcass depend on genetic basis of fatteners (Djikić and Jurić, 2003). According to statements by same authors, regression coefficients between total increase of muscle tissue in carcass in relation to the same tissue in individual carcass parts show that it is possible to produce meat pigs with different disptribution of tissues in the carcass according to market demands and using selection measures.

In order to objectively value the quality of pig carcasses, this work starts on the slaughter line using: two point method (ZP-Zwei-Punkt), and then on warm right carcass sides using FOM device. Published results obtained by other authors (Luković et al., 2000; Timanović 2003; Pulkrábek et al.,2003; Kušec et al. 2006; Kosovac et al., 2007; Zekić et al., 2007) confirm that categorization of pig carcass sides into SEUROP classes using two point method (ZP - Zwei-Punkt) and instrumental method on warm right carcass sides using FOM device differ greatly, which indicates the need to develop new equations for assesment of the share of muscle tissue in pig carcass sides.

Objective of this paper is to compare obtained results of the meat yield on slaughter line using modern methods of evaluation, and primarily in this paper we point out phenotypic correlation between certain parameters of the quality of pig carcasses.

\section{Material and methods}

Investigation included 117 fatteners of Swedish Landrace breed reared on single farm in Vojvodina. Fatteners included in this research were housed in unconventional conditions, on deep litter, and in the fattening straw was used as deep litter with $1,5 \mathrm{~kg}$ of straw per fatteners. Nutrition of fatteners was ad 
libitum and usual feed mixture for fatteners was used, and they were kept in groups of 12 to 15 heads during fattening.

Maintenance of adequate microclimatic conditions was realized by automatic ventilation, and heating of the facility by system of self-heating. Trial lasted 116 days, and at the end of trial pigs were weighed and average mass at slaughtering was $103,48 \mathrm{~kg}$. On slaughter line, the weight of warm carcass sides was measured, also weight of cold carcass side, length of carcass side "a" from os pubis do 1st rib, and carcass side length " $\mathrm{b}$ " from os pubis to atlas.

On slaughter line the meat yield was evaluated in two ways:

1. Mannually by method of "two points,, where for the assessment of carcass side meat yield measures of fat tissue on two points were taken:

$\mathrm{X}_{1=}$ thickness of fat tissue (with skin) in milimeters measured on medial carcass surface between 3rd and 4th lumbal vertebrae, caudo-cranially, and $\mathrm{X}_{2}$ =thickness of fat tissue (with skin) in milimeters measured on medial carcass surface between $3 \mathrm{rd}$ and 4 th rib, caudo-cranially.

Linear measures $X_{1}$ and $X_{2}$ were taken mannualy using ruler and mathematical formula calculated through setting of linear multiple regression modle with two independent variables, defined by Džinić et al. (2004) and meat yield of each pig carcass side was calculated.

Equation for calculation of the meat percentage by method of "two points,:

$$
\mathrm{Y}=67.098-0.505 \mathrm{X}_{1}-0,14 \mathrm{X}_{2}
$$

2. The following mathematical model FOM device for calculation of the percentage of meat in carcass sides defined by Petrović et al. (1996):

$$
\mathrm{Y}=63.578-0.6673 \times \mathrm{LF}-0.9191 \times \mathrm{RF}+0.0192 \times(\underline{\mathrm{LF}+\mathrm{RF}})+0.2112 \times \mathrm{RM}
$$

where:

$\mathrm{Y}=$ calculated percentage of meat in carcass side

$\mathrm{LF}=$ thickness of fat tissue (with skin) in milimeters measured $8 \mathrm{~cm}$ of the medial line of carcass between 3rd and 4th lumbal vertebrae, caudo-cranially, $\mathrm{RF}=$ thickness of fat tissue (with skin) in milimeters measured $7 \mathrm{~cm}$ of the medial line of carcass between 3rd and 4th rib, caudo-cranially $\mathrm{RM}=$ diameter of $\mathrm{M}$. longisimus dorsi (MLD) in millimiters, measured on same point and in same time as RF.

The correlation between some qualitative parameters of pig carcasses and relative shares of muscle tissue in carcass sides was investigated. 
Statistical processing of data was done using method of descriptive statistics - statistical software STATISTIKA 8. (University licence Novi Sad, 2008.).

\section{Results and discussion}

Mean values and variability of parameters of pig carcass quality are presented in table 1. Pigs were fattened to average mass of $103,48 \mathrm{~kg}$. Meat yield of carcass sides assessed using FOM device was 56,29\%, and by method of "two points" 53,16\%. Luković et al. (2000), Timanović (2003), Pulkrábek et al (2003), Pulkrábek et al. (2004), Kušec et al. (2006) and Kosovac et al. (2007) in their research stated lower values of meat percentage in carcass sides $(49,20-55,52 \%)$ compared to values obtained in this research with FOM device, which are in concordance with vlaues obtained by Tomovic, (2002). However, our data on yield of musle tissue in carcass sides obtained by method of "two points" are lower than results stated by Kušec et al., (2004), Kosovac et al., (2007) and Zekić et al., (2007).

In regard to data related to mass of warm carcass sides and mass of cold carcass sides $(83,81$ and $39,33 \mathrm{~kg})$ they are in concordance with results obtained by majority of authors.

In table 2 the phenotypic correlation and dependence between carcass quality traits and assessment of meat yield of pigs determined using different methods are presented. Strength and direction of correlation were different depending on the investigated parameters. Correlation of live mass, weight of warm and cold carcasses with total meat yield evaluated using method of "two point" and FOM device was negative, weak and statistically insignificant, which is in accordance with results obtained by Pulkrábek et al. (2004) and other authors who also concluded negative correlation between weight of carcass side and percentage of meat in carcass side.

Also, the correlation between thickness of fat tissue $\left(\mathrm{X}_{1}\right.$ and $\left.\mathrm{X}_{2}\right)$ and meat yield of carcass side determined using method of »two point « was negative, strong and statistically very significant $\left(-0,97^{* *}\right.$ and $\left.-0,77^{* *}\right)$ which means that meat yield of carcass sides decreased with the increase of thickness of fat tissue. Senčić et al. (2002), Pulkrábek et al. (2003) and Pulkrábek et al. (2004) have determined that the best indicator of meat yield of pig carcass sides as well as potential selection criteria is thickness of rump fat tissue ( $r=-0,85^{* *}$ and $\left.\mathrm{r}=-0,75^{* *}\right)$. 
Table 1. Average values of the carcass quality of investigated pigs

\begin{tabular}{|l|c|c|}
\hline \multirow{2}{*}{ Trait } & \multicolumn{2}{|c|}{ Parameter } \\
\cline { 2 - 3 } & Average & Sd \\
\hline Live mass $(\mathrm{kg})$ & 103,48 & 3,47 \\
\hline Weight of warm carcass side $(\mathrm{kg})$ & 83,81 & 3,06 \\
\hline Weight of cold carcass side (kg) & 39,33 & 1,49 \\
\hline Carcass side length “a (cm) & 83,59 & 2,62 \\
\hline Carcass side length "b (cm) & 99,89 & 3,24 \\
\hline Fat thickness $\mathrm{X}_{1}(\mathrm{~mm})$ & 21,85 & 3,47 \\
\hline Fat thickness $\mathrm{X}_{2}(\mathrm{~mm})$ & 20,78 & 4,52 \\
\hline LF (mm) & 18,33 & 4,08 \\
\hline RF (mm) & 14,92 & 3,73 \\
\hline RM - diameter MLD (mm) & 62,33 & 5,25 \\
\hline Two point - ZP-Zwei-Punkt ( \% ) & 53,16 & 2,15 \\
\hline FOM (\%) & 56,29 & 3,83 \\
\hline
\end{tabular}

Obtained values of correlation of thickness of fat tissue (LF and RF) and meat yield of carcass sides using FOM method were negative, strong and statistically very significant: $-0,85^{* *}$ and $-0,87^{* *}$. Diameter of the long back muscle (MLD) was in positive and medium strong correlation $\left(0,48^{*}\right)$ with calculated percentage of meat in the carcass.

Table 2. Phenotypic correlations between investigated traits

\begin{tabular}{|l|c|c|}
\hline \multicolumn{1}{|c|}{ Traits } & TP \% of muscle tissue & FOM \% of muscle tissue \\
\hline Live mass $(\mathrm{kg})$ & $-0,02$ & $-0,20$ \\
\hline Weight of warm carcass side $(\mathrm{kg})$ & $-0,20$ & $-0,31$ \\
\hline Weight of cold carcass side $(\mathrm{kg})$ & $-0,15$ & $-0,17$ \\
\hline Carcass side length "a (cm) & $-0,07$ & $-0,07$ \\
\hline Carcass side length "b $(\mathrm{cm})$ & $-0,12$ & $-0,11$ \\
\hline Fat thickness $\mathrm{X}_{1}(\mathrm{~mm})$ & $-0,97^{* *}$ & $-0,26$ \\
\hline Fat thickness $\mathrm{X}_{2}(\mathrm{~mm})$ & $-0,77^{* *}$ & $-0,14$ \\
\hline LF $(\mathrm{mm})$ & $-0,36$ & $-0,85^{* *}$ \\
\hline RF $(\mathrm{mm})$ & $-0,22$ & $-0,87^{* *}$ \\
\hline RM $(\mathrm{mm})$ & $-0,20$ & $0,48^{*}$ \\
\hline
\end{tabular}


For the purpose of easier consideration of results presented in table 2, in graphs $1,2,3$ and 4 the effect of fat tissue thickness and back fat thickness $\left(\mathrm{X}_{1}\right.$, $\mathrm{X}_{2}$, LF i RF) on variability of the share of muscle tissue in the carcass is presented. Presented graphs show the presence of negative regression of fat tissue thickness on yield of muscle tissue in carcass since points on dispersion diagram move in direction from upper left corner towards low right corner. This means that with the increase of thickness of fat tissue and back fat tissue the share of muscle tissue in carcass decreases by $-0,6195 ;-0,3674 ;-0,7991$ and $0,8970 \%$.

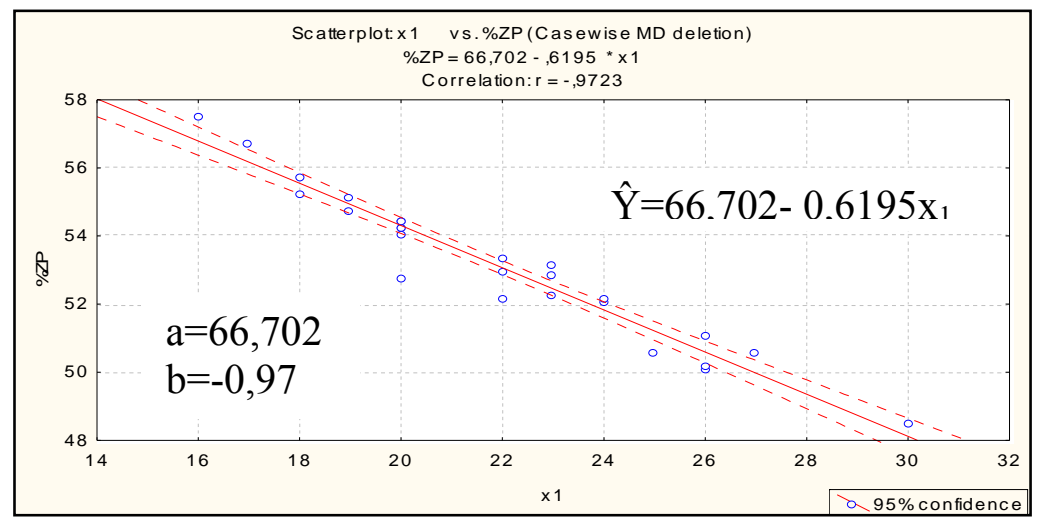

Graph 1. Dispersion diagram and interpolated regression line of meat yield on thickness of fat tissue $X_{1}$

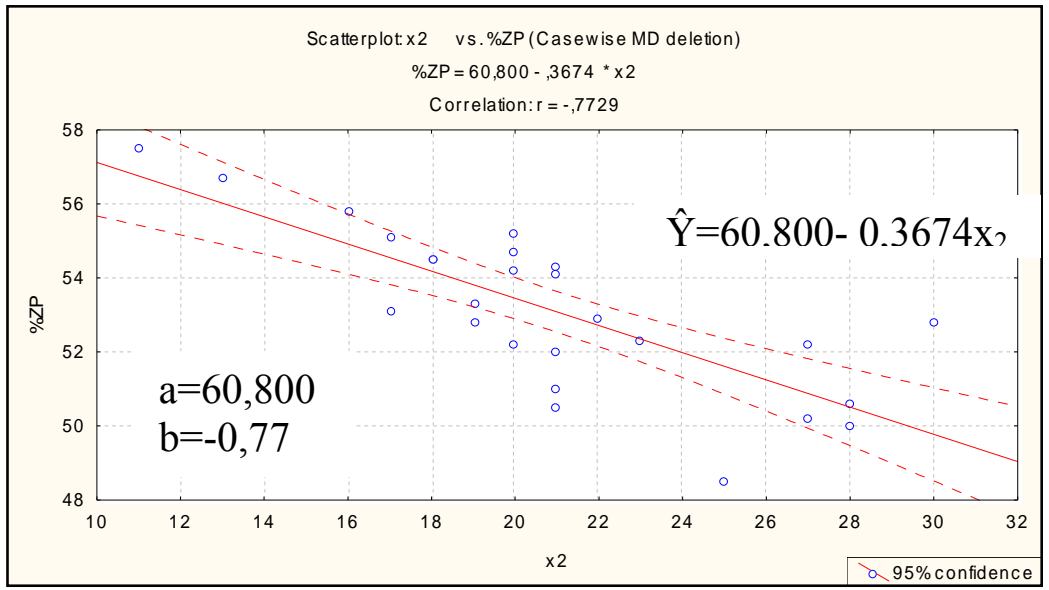

Graph 2. Dispersion diagram and interpolated regression line of meat yield on thickness of fat tissue $\mathrm{X}_{2}$ 


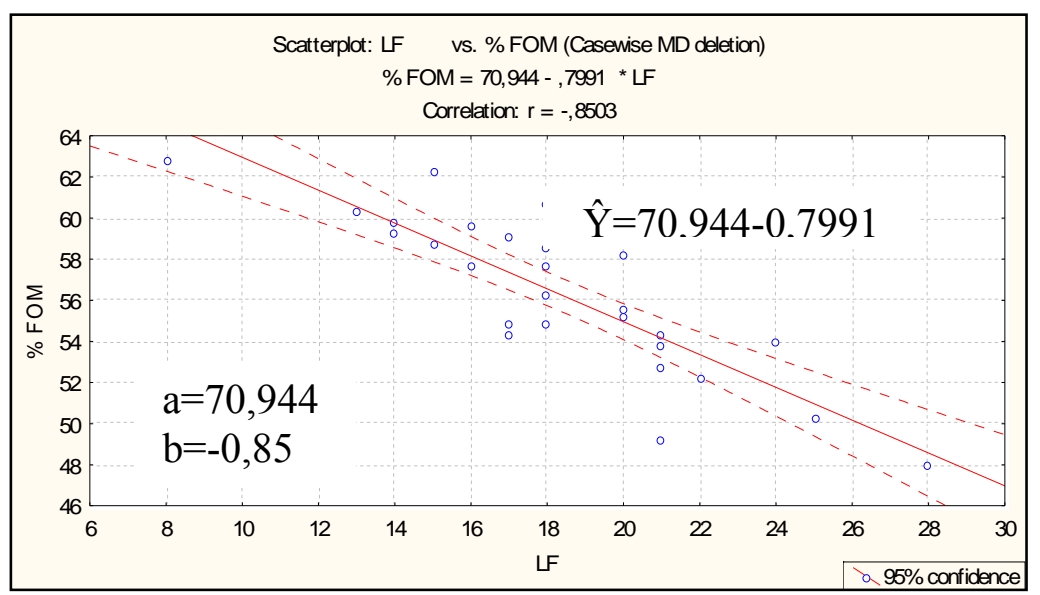

Graph 3. Dispersion diagram and interpolated regression line of meat yield on thickness of fat tissue between 3rd and 4th lumbal vertebrae

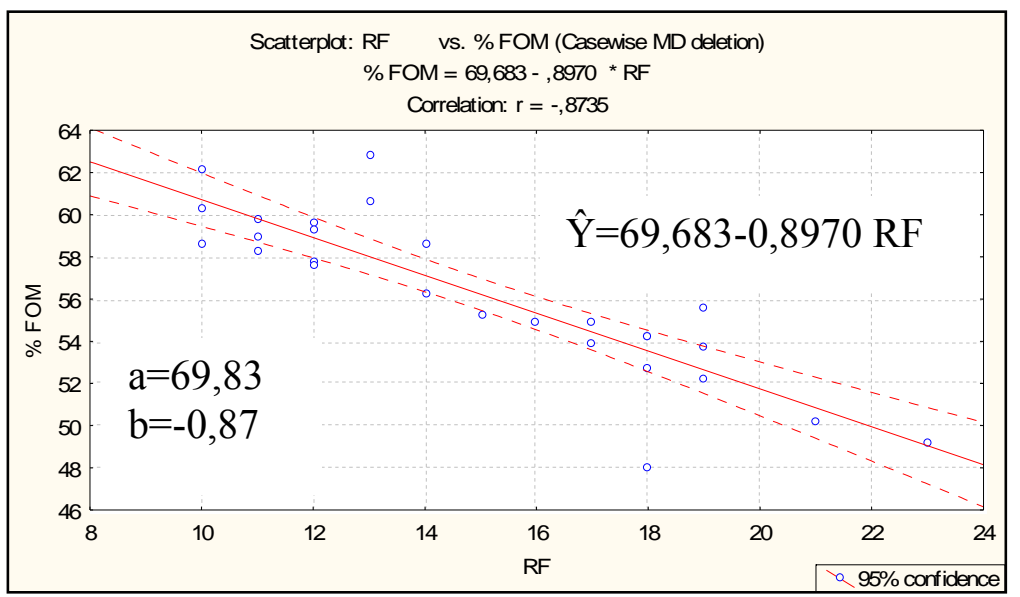

Graph 4. Dispersion diagram and interpolated regression line of meat yield on thickness of fat tissue between 3rd and 4th rib

Dispersion diagram on graph 5 shows that most of the points are grouped from bottom left corner towards upper right, which indicates presence of postive regression of share of muscle tissue in carcass on dimater of MLD 
$(\hat{\mathrm{Y}}=34,390+0,35140 \mathrm{RM})$. It is obvious from results that there is positive correlation, medium strong, between MLD diameter and meat yield in pig carcasses $\left(\mathrm{r}=0,48^{*}\right)$. Based on value of the determination coefficient $\left(\mathrm{r}^{2}=23,04 \%\right)$ it is concluded that dependance of the share of muscle tissue in pig carcasses is explained with $23,04 \%$ effect of the size of dimater of MLD and with $76,96 \%$ by effect of other not investigated factors (non-determination coefficient $\mathrm{k}^{2}=76,96 \%$ ).

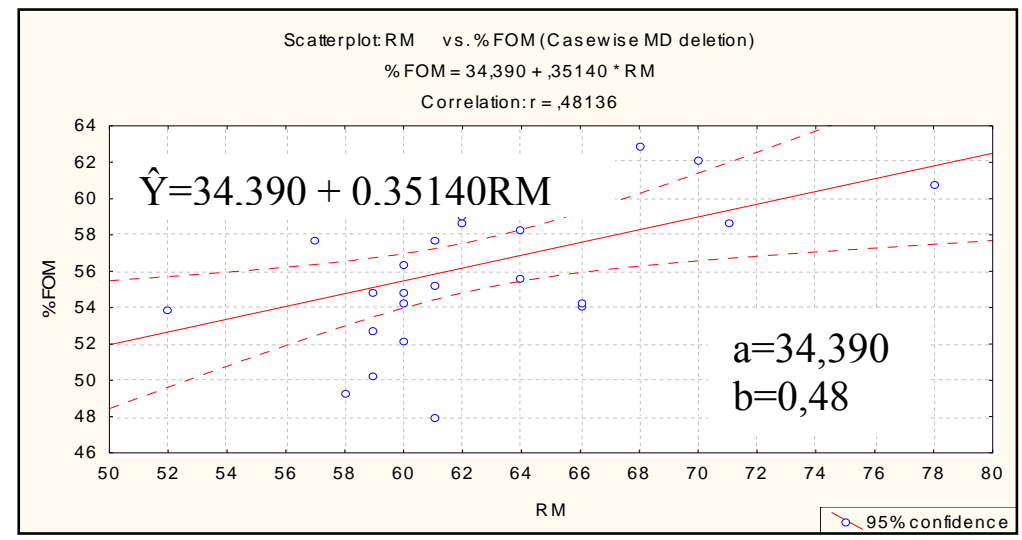

Graph 5. Dispersion diagram and interpolated regression line of meat yield on MLD diameter

\section{Conclusion}

Based on presented results of the research it can be concluded that average values of the pig carcass quality in investigated heads of Swedish Landrace were: mass at slaughtering $(103,48 \mathrm{~kg})$, weight of warm carcass sides $(83,81 \mathrm{~kg})$, weight of cold carcass side $(39,33 \mathrm{~kg})$, carcass length „a" $(83,59$ $\mathrm{cm})$ and carcass length ,b" $(99,89 \mathrm{~cm})$ and are similar to results of research by other authors and indicate satisfactory conditions of housing (unconcentional conditions).

Of main indices of pig carcass quality, the strongest correlation with meat yield of carcass sides (by method ,of two points" $\bar{E}$ ) was established for thickenss of fat tissue $X_{1}$ and $X_{2}\left(-0,97^{* *}\right.$ and $\left.-0,77^{* *}\right)$. The strongest correlation with the share of muscle tissue in carcass (by instrumental method FOM) was established for fat tissue thickness LF and RF $\left(-0,85^{* *}\right.$ and $0,87^{* *}$ ), whereas the diameter of the long back muscle (MLD) was in positive 
and medium strong correlation $\left(0,48^{*}\right)$ with calculated percentage of meat in carcass.

Results of the assessment of quality of pig carcasses obtained using method of two points $(53,16 \%)$ and by instrumental method on right carcass sides using FOM device (56,29\%) differed, which indicates need to develop new equations for evaluation/assessment of share of muscle tissue in pig carcasses.

\title{
KORELATIVNI ODNOSI IZMEDJU NEKIH POKAZATELJA KVALITETA SVINJSKUH TRUPOVA U NEKONVENCIONALNIM USLOVIMA DRŽANJA
}

\author{
O. Kosovac, B. Živković, T. Smiljaković, Č.Radović
}

\section{Rezime}

U radu su prikazani važniji kvalitativni parametri svinjskih trupova rase švedski landras. Ispitivana je i fenotipska povezanost pokazatelja kvaliteta svinjskih trupova sa mesnatošću polutki. Tovljenici obuhvaćeni ovim ispitivanjem (117) držani su u nekonvencionalnim uslovima, na dubokoj prostirci, a kao prostirka u tovu korišćena je slama.

$\mathrm{Na}$ liniji klanja ocenjena je mesnatost svinjskih polutki metodom "dve tačke (Džinić et al. 2004) i matematičkim modelom FOM-uredjajem (koji su definisali Petrović et al. 1996). Mesnatost polutki procenjena FOM-uredjajem iznosila je $56,29 \%$, a metomom "dve tačke,, 53,16\%. Od osnovnih pokazatelja kvaliteta svinjskih trupova u najjačoj povezanosti s mesnatošću polutki (procenjene FOM-uredjajem) bila je debljina masnog tkiva LF i RF i debljina slanine $\mathrm{X}_{1}$ i $\mathrm{X}_{2}$ (ocenjena metodom "dve tačke"'). Ustanovljene korelacije su bile negativne, jake i statistički značajne $\left(-0,85^{* *} ;-0,87 * *\right.$ i $-0,97 * *$; $0,77^{* *}$.Dobijeni rezultati vrednovanja kvaliteta svinjskih trupova metodom "dve tačke" (53,16\%) i instrumentalnom metodom na toplim desnim polutkama, FOM-uredjajem $(56,29 \%)$ odstupaju, što ukazuje na potrebu izrade nivih jednačina za procenu udela mišićnog tkiva u trupovima svinja.

Ključne reči: kvalitet trupa, korelacije, landras 


\section{References}

KOSOVAC O., JOSIPOVIĆ S., ŽIVKOVIĆ B., RADOVIĆ Č., MARINKOV G., TOMAŠEVIĆ D. (2007). Comparable presentation of carcass and meat quality of different pig genotypes using modern evaluation methods. . 2nd International Congress on animal husbandry "New perspectives and challenges of sustainable livestock farming", Belgrade-Zemun-Serbia, October 03-05 2007. Biotechnology In Animal Husbandry, 23, (5-6), 291-301.

KUŠEC G., DJURKIN I., PETRIČEVIĆ A., KRALIK G., MALTAR Z. (2006): Influence of sex on tissue distribution in pig carcasses. Krmiva, 48, (3), $131-142$.

LUKOVIĆ Z., UREMOVIĆ M., HRABAK V., UREMOVIĆ Z., AMBRUŠEC LJ. (2000): Difference in Predicting Swine Meatiness as a Result of Different Measurement. Agriculturae Conspectus Scientificus 65, (4), 213217.

PETROVIĆ LJ., MANOJLOVIĆ D., DŽINIĆ N., LATOVSKA E., VELIMIR J., ADAMOVIĆ J. (1996): Evaluation of carcass and meat quality on the slaughterline of pigs with FOM-device. 12nd ICoMST, Proceedings, G-7, 246. lillehammer, Norway.

PULKRÀBEK J., PAVLIK J., VALIŠ L., ČECHOVẢ M. (2003): Pig carcass classification based on the Iean meat content. Sbornik Mendlovy zemědělskẻ a lesnickẻ univerzity, Brno, 51, 109-114.

PULKRÁBEK J., PAVLíK J., VALIŠ L. (2004): Pig carcass quality and $\mathrm{pH}_{1}$ values of meat. Czech J. Anim.Sci., 49, (1), 38-42.

TIMANOVIĆ S. (2003): Efekat različitih modela selekcije i šema ukrštanja na prinos i kvalitet mesa svinja. Doktorska disertacija, Poljoprivredni fakultet, Novi Sad.

TOMOVIĆ V.(2002). Uticaj selekcije i višerasnog ukrštanja svinja na kvalitet polutki i tehnološki, nutritivni i senzorni kvalitet mesa. Magistarski rad. Tehnološki fakultet, Novi Sad

ZEKIĆ V, OKANOVIĆ DJ., ŽIVKOVIĆ B. (2007): Ekonomski aspekti proizvodnje svinjskog mesa. Savremena poljoprivreda 56, (1-2), 206-211.

DŽINIĆ N., PETROVIĆ LJ., TOMOVIĆ V., MANOJLOVIĆ D. (2004): "Definisanje matematičkog modela za utvrdjivanje prinosa mesa u polutkama svinja metodom dve tačke", Simpozijum: "Veterinarstvo i stočarstvo u proizvodnji zdravstveno bezbedne hrane“, Zbornik kratkih sadržaja, 28, Herceg Novi.

DJUIKIĆ M., JURIĆ I. (2003): Odnosi i raspodjela tkiva kod svinja kao čimbenici konkurentnosti na tržištu svinjskog mesa. XXXVIII Znanstveni skup hrvatskih agronoma. Optija, Hrvatska, 19-21 veljče, Zbornik radova 479-482. 